\title{
DOES INCLUDED BARK REDUCE THE STRENGTH OF CODOMINANT STEMS?
}

\section{by E. Thomas Smiley}

Abstract. One of the most common locations for the aboveground portion of a tree to fail is at the junction of two or more codominant stems. Due to the frequency of failures at this point, a study was undertaken to get a better understanding of the mechanical strength of this point and to determine if included bark reduces the strength of the union. Eighty-four codominant stems were removed from 26 felled maple trees. These crotches were securely anchored and split apart using measured force. Breaking force varied from 64 to $2,363 \mathrm{~kg}$. The regression line produced from the comparison of stem diameter and force required for breaking the union when there was no included bark was Force $=$ Diameter $* 613-1388, r^{2}=0.92$. When only those unions with included bark were analyzed, the regression line was Force $=$ Diameter $* 537-1285, r^{2}=0.76$. There was a significant difference between the regression lines $(p<0.05)$. Codominant stems that have bark trapped in the union are significantly weaker than those that do not have bark included. The differences appear to be greater with smaller-diameter stems than with larger stems.

Key Words. Pruning; cabling; bracing; tree failure; Acer rubrum.

One of the most common locations for the aboveground portion of a tree to fail is at the junction of two or more codominant stems. Matheny and Clark (1994) state that codominant stems with included bark do not form connective tissues between stems and are prone to failure. In earlier studies, there were indications that included bark did make these junctions weaker (Smiley et al. 2000). Due to the frequency of failures at this point, this study was undertaken to get a better understanding of the mechanical strength of this point and to determine if included bark reduces the strength of the union.

\section{MATERIALS AND METHODS}

Twenty-six red maple (Acer rubrum L.) trees were harvested between June 1999 and July 2001 at the Bartlett Tree Research Laboratories in Charlotte, North Carolina, U.S. Eighty-four codominant stems were removed from the felled trees, leaving at least $45 \mathrm{~cm}$ of stem on either side of the crotch. Crotches were tested within 3 days of harvest to avoid drying of the wood. Stem diameter was measured 30 $\mathrm{cm}$ below and above the crotch. Diameters ranged from 4.9 to $23.4 \mathrm{~cm}$.

The crotches were fastened to a large tree trunk using chains $30 \mathrm{~cm}$ above and below the crotch (Figure 1). A snatch block was fastened to the nonanchored stem at 30 $\mathrm{cm}$ above the crotch. A Dillon $1,818 \mathrm{~kg}$ peak reading mechanical dynamometer (Weight-Tronix, Fairmont, MN) was chained to a second tree and served as an anchor point for a steel cable that ran through the snatch block to an electric winch. The cables from the tree to the snatch block and from the snatch block to the winch were nearly parallel and remained the same throughout the trial. The winch was activated until the crotch broke. The peak reading on the dynamometer was recorded and multiplied by two to derive the force required to break the crotch.

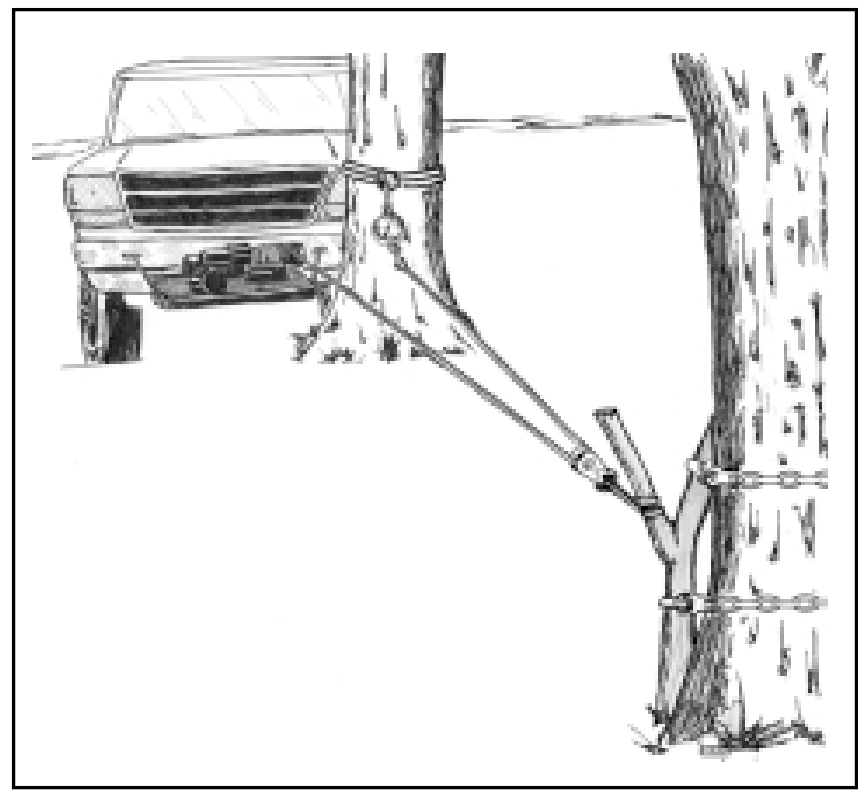

Figure 1. The crotches were fastened to a large tree trunk using chains $30 \mathrm{~cm}$ above and below the crotch. A snatch block was fastened to the nonanchored stem at $30 \mathrm{~cm}$ above the crotch. A Dillon $1,818 \mathrm{~kg}$ peak reading mechanical dynamometer was chained to a second tree and served as an anchor point for a steel cable that ran through the snatch block to an electric winch; cables were nearly parallel. The winch was activated until the crotch broke. 
Regression lines were compared for slope and Yintercept using the general linear test approach (Neter and Wasserman 1974).

\section{RESULTS}

Stem breakage occurred in consistent patterns. The failure occurred at the junction between the codominant stems and separated the two stems evenly (Figure 2). If included bark was present, the break always exposed it. The amount of included bark varied greatly among samples.

Breaking force varied from 64 to 2,363 kg (Figure 3). The regression line produced from the comparison of stem diameter and force required for breaking the union when there was no included bark was Force $=$ Diameter * $613-$ 1388. The $r^{2}$ value was 0.92 . When only those unions with included bark were analyzed, the regression line was Force $=$ Diameter $* 537-1285$. The $r^{2}$ value was 0.76 . There was a significant difference between the regression lines $(p<0.05)$.

As an example of the regression, a crotch $10 \mathrm{~cm}$ in diameter breaks at 392 and $484 \mathrm{~kg}$ for the included bark samples versus the nonincluded bark, respectively. For $15 \mathrm{~cm}$ diameter crotches, the break points are 880 and $1,040 \mathrm{~kg}$, respectively; for $25 \mathrm{~cm}$ crotches, they are 1,857 and 2,155 $\mathrm{kg}$, respectively.

\section{DISCUSSION}

Codominant stems that have bark trapped in the union are significantly weaker than those that do not have bark included. The differences appear to be greater with smallerdiameter stems than with larger stems. Using results from the regression analysis at 10 and $25 \mathrm{~cm}$, the $10 \mathrm{~cm}$ stems are almost $20 \%$ weaker when bark is present. At $25 \mathrm{~cm}$, included bark stems are only 14\% weaker than nonincluded bark unions.

Due to the relatively low reduction in breaking strength at larger diameters, all codominant stem junctions should be considered weak. If trees with codominant stems have a target present that could be damaged if failure occurs, remedial treatments should be applied.

\section{LITERATURE CITED}

Matheny, N.P., and J.R. Clark. 1994. A Photographic Guide to the Evaluation of Hazard Trees in Urban Areas. International Society of Arboriculture, Champaign, IL. 85pp.

Neter, J., and W. Wasserman, 1974. Applied Linear Statistical Models. R.D. Irwin, Inc., Homewood IL. 842 pp.

Smiley, E.T., C.M. Greco, and J.G. Williams. 2000. Brace rods for codominant stems: Installation location and breaking strength. J. Arboric. 26(3):170-176.

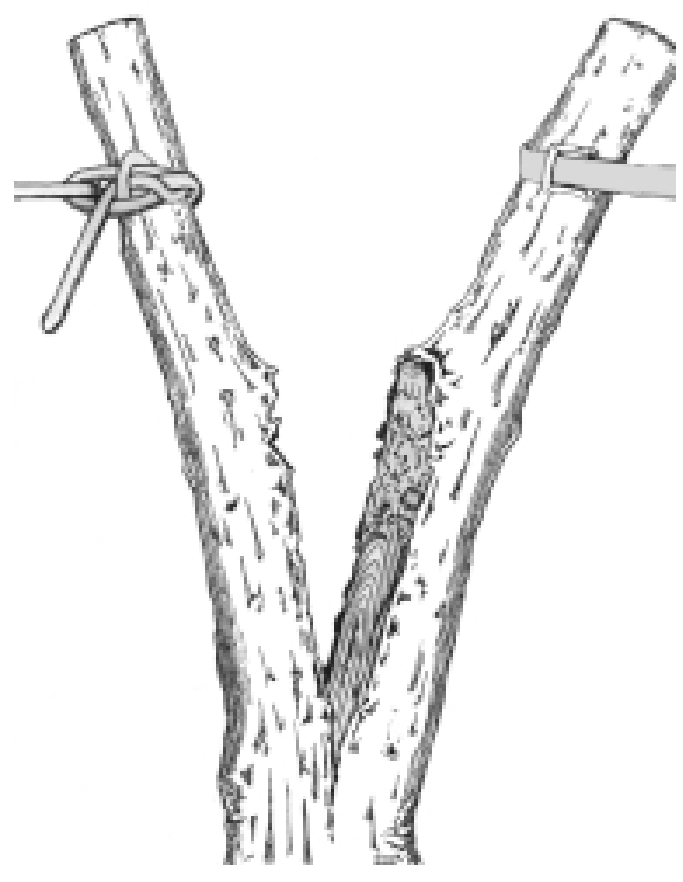

Figure 2. Failure of codominant stems occurred at the junction between the codominant stems and separated the two stems evenly.

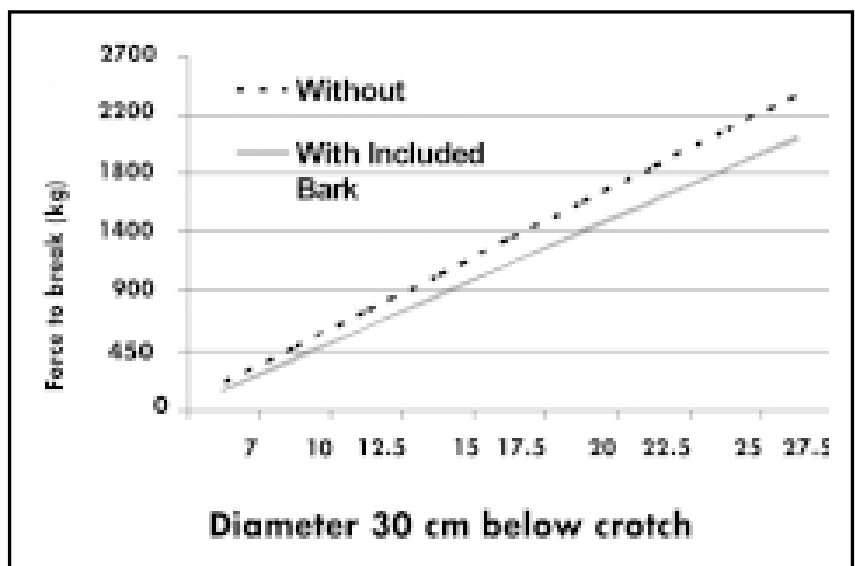

Figure 3. Force required to break codominant stems of different diameters. Diameter was measured $30 \mathrm{~cm}$ below the junction. 
Acknowledgments. We would like to acknowledge the following people who contributed to this research project: F. Dan Thompson for engineering advice; Elden LeBrun and Elizabeth Gilbert for technical support; Joe Bones for safety recommendations; John C. Weiss of Dyna-Marq of Houston, Texas, for providing the dynamometer; Tom Martin for assistance with the design of the experiment; Donnie Merritt for the drawings; James G. Williams, a statistician with the Department of Forestry, retired, Clemson University, Clemson, South Carolina; and Bruce R. Fraedrich, director of the Bartlett Tree Research Laboratories.

\section{Arboricultural Researcher \\ Bartlett Tree Research Laboratories \\ 13768 Hamilton Road \\ Charlotte, NC 28278, U.S. \\ (Also, Adjunct Professor, Clemson University)}

Résumé. Une des plus fréquentes zones où la portion aérienne d'un arbre peut se briser est le point de jonction entre deux ou plusieurs branches codominantes. En raison de la fréquence de bris à cet endroit, une étude a été menée afin de mieux comprendre le mécanisme des forces à ce niveau et pour déterminer si l'écorce incluse diminue la résistance au point de jonction. Quatre-vingt-huit branches codominantes ont été recueillies d'érables tombés au sol. Ces fourches ont été solidement ancrées et fendues par la suite en y exerçant une force. La force de bris variait de 64 à $2363 \mathrm{~kg}$. La droite de régression produite en regard de la comparaison entre le diamètre de la branche et la force requise pour briser la fourche, et ce lorsqu'il n'y avait pas d'écorce incluse, était: Force $=$ Diamètre $\times 613-1388, \mathrm{r}^{2}=$ 0,92 . Lorsque seules les fourches avec écorce incluse étaient analysées, la droite de régression était: Force $=$ Diamètre $\times 537-1285, \mathrm{r}^{2}=0,76$. Il y avait une différence significative entre les deux droites de régression $(p<0,05)$. Les branches codominante qui ont de l'écorce prise au niveau du point de jonction sont significativement plus faibles que celles qui n'ont pas d'écorce incluse. Les différences apparaissent être plus grandes pour des branches de plus faibles diamètres que celles dont le diamètre est plus élevé.

Resumen. Uno de los lugares para que falle la porción superior de un árbol es la unión de dos o más ramas codominantes. Debido a la frecuencia de fallas en este punto, se llevó a cabo un estudio para lograr un mejor entendimiento de la resistencia mecánica en este punto y para determinar si la corteza incluida reduce la fuerza de la unión. Se removieron ochenta y cuatro tallos codominantes de árboles derribados de maple. Estas horquillas fueron ancladas y separadas con el uso de una fuerza medida. La fuerza de ruptura varió de 64 a $2363 \mathrm{Kg}$. La regresión linear producida de la comparación del diámetro del tronco y la fuerza requerida para el rompimiento de la unión cuando no había corteza incluida fue: Fuerza = Diámetro * 613 $1388, r^{2}=0.92$. Cuando se analizaron solamente uniones con corteza incluida, la regresión linear fue: Fuerza $=$ Diámetro * $537-1285, r^{2}=0.76$. Hubo una diferencia significativa entre las líneas de regresión $(p<0.05)$ Los tallos codominantes que tienen corteza atrapada en su unión son significativamente más débiles que los que no tienen corteza incluida. Las diferencias parecen ser mayores con tallos de diámetro pequeños que con grandes tallos. 